Tokyo Electric Power Company (TEPCO). The Japanese government on 3 September announced a plan to take over the clean-up, but its intervention is overdue.

In the two and a half years since the accident, TEPCO has repeatedly failed to acknowledge the nature and seriousness of problems with safeguarding nuclear fuels in the three destroyed reactors at Fukushima. Each day, some 400,000 litres of water are being funnelled into the reactor cores to prevent the rods from overheating. Only in recent months has TEPCO admitted that some contaminated water is leaking into the reactor basement and, through cracks in the concrete, into the groundwater and the adjacent sea. Few independent measurements of radiation exposure are available, and it is worryingly unclear how these leaks might affect human health, the environment and food safety. But the problems do not stop there. There are now almost 1,000 storage tanks holding the used cooling water, which, despite treatment at a purification system, contains tritium and other harmful radionuclides. The leaks make clear that this system is a laxly guarded time bomb.

It is no secret that pipes and storage tanks sealed with rubber seams have a habit of leaking. TEPCO's reliance on routine patrols to detect any leaks has been careless, if not irresponsible. That the company, in response to the latest incidents, intends to refit the tanks with sensors and extra safety controls just underlines the makeshift way in which the storage facilities were set up in the first place. Meanwhile, the fate of the constantly amassing polluted water is undecided. Proposals earlier this year to dump it into the sea understandably met with fierce opposition from local fisheries.

Given the government's past actions and information policies, one might doubt whether it would be any more competent than TEPCO at managing the situation and communicating it to the public. Over the weekend, it turned out that radiation doses near the leaking tanks

are 18 times larger than first reported: leakage that started as a mere 'anomaly' has turned into a genuine crisis. Japan should start consulting international experts for help. The United States, Russia, France and the United Kingdom - to name but a few - all have know-how in nuclear engineering, clean-up and radiation health that would serve Japan well. An international alliance on research and clean-up would help to restore shattered public trust in the usefulness and effectiveness

"Aninternational alliance on research and clean-up would help to restore shattered public trust."

$$
\text { of monitoring and crisis-mitigation. }
$$

The most important impacts of the leaks will be those on the sea off Fukushima and the larger Pacific Ocean, which must be closely monitored. After assessments by US and Japanese scientists in 2011 and 2012, two major questions remain unanswered. How much radioactivity is still entering the sea? And, given the high levels of radioactivity that have been measured in some species long after the accident, when will fish and seafood from the region be safe to consume? The leaks make it more urgent to find answers to these questions.

To make reliable assessments of any environmental effects, scientists need to be able to collect data on contamination of marine food webs with all long-lived radionuclides, and particularly with caesium-137, strontium-90 and plutonium-239. They also need to know the sources of contamination, and to study the transport of radionuclides in groundwater, sediments and ocean currents. Current Japanese Prime Minister Shinzo Abe and his government have promised to boost science; they should encourage and support researchers from around the world in collecting and sharing information. Chernobyl was a missed opportunity for post-accident research — in that sense at least, Fukushima could do much better.

\section{The nitrogen fix}

\section{A simple iron complex offers a chance to update how the global supply of ammonia is made.}

W hen it comes to the natural processes of plants, photosynthesis tends to hog attention. If researchers could efficiently copy the ability to convert sunlight to energy, chemists promise, our energy problems would be over. They have not managed it yet.

They have had more luck with harnessing and mimicking the lessheralded, but just as important, process of nitrogen fixation - the conversion of nitrogen from the air into ammonia, which can be used by plants to make DNA, RNA and proteins, and by industry to make fertilizers and explosives. On page 84 , chemists announce the discovery of an important piece of the puzzle. Jonas Peters and his colleagues at the California Institute of Technology (Caltech) in Pasadena have identified a small iron complex that efficiently catalyses the conversion.

The discovery comes a full century after the chemist Carl Bosch opened his nitrogen works in Oppau, Germany, and in doing so sealed the deaths of millions of people, and the birth and survival of billions more. Bosch had worked out how to scale up a laboratory reaction to combine nitrogen from the air and hydrogen from natural gas into synthetic ammonia. Textbooks talk about the Haber process, named after German chemist Fritz Haber, who made the theoretical breakthrough, but it is more properly called the Haber-Bosch process. Both Haber and Bosch won Nobel prizes for their work.

It is hard to overstate the impact of the Haber-Bosch process. A figure published in 2008 (the centenary of Haber's patent) shows how the increase in world population since 1960 has kept step with increases in the use of nitrogen fertilizer (J. W. Erisman et al. Nature Geosci. 1, $636-639 ; 2008)$. Population growth through access to fertilizer and

therefore food was one of Haber's goals in developing his process. The other was to give Germany mastery of the science of munitions. Both goals demanded that the industrial supply of fixed nitrogen grew from the few hundreds of thousands of tonnes available per year at the start of the twentieth century, when it relied on natural resources such as guano and mineral saltpetre (potassium nitrate and sodium nitrate).

Bosch had to treat nitrogen and hydrogen under massive pressure and heat to make the conversion to ammonia. In industry, the process is still done in the same expensive and energy-intensive way.

Crucially, the synthesis described by the California group unfolds under mild, environmentally friendly conditions, just as it does in nature. (Well, when the conversion is done in the soil - another way to fix nitrogen naturally is through the searing flash of a lightning strike.) Peters and his colleagues examined the enzymes and cofactors that make ammonia among the roots of plants such as legumes. Iron has for decades been known to be important in these cofactors, but exactly how and why have been a mystery. For a while, attention switched to molybdenum, which chemists showed could also help to make ammonia, but biochemical and spectroscopic data have renewed the focus on iron. The finding from the Caltech scientists supports this: the iron complex they identify can do the job with no need for molybdenum.

It took less than five years for Bosch to commercialize Haber's discovery, and to revolutionize the industrial supply of ammonia. It will probably take longer for researchers to build on the latest work, but at least now they have a platform.

The stakes have always been high. In the nineteenth century, Peru and Chile fought a war over guano. When Germany was denied access to Chile's saltpetre during the First World War, the Haber-Bosch process gave it - and the world - an alternative, which it grasped with both

$\checkmark$ NATURE.COM To comment online, click on Editorials at: go.nature.com/xhunqv hands. All the time, legumes such as alfalfa, peanut and clover have been quietly and efficiently doing their thing. A century after Bosch, they could help to write a new chapter in the ammonia story. And photosynthesis? Watch this space. 